\title{
Ocean Acidification Mitigates the Negative Effects of Increased Sea Temperatures on the Biomineralization and Crystalline Ultrastructure of Mytilus
}

\author{
Antony M. Knights ${ }^{1 *}$, Matthew J. Norton ${ }^{1}$, Anaëlle J. Lemasson ${ }^{1,2}$ and Natasha Stephen ${ }^{3}$ \\ ${ }^{1}$ Marine Biology and Ecology Research Centre, School of Biological and Marine Sciences, University of Plymouth, Plymouth, \\ United Kingdom, ${ }^{2}$ Wild Planet Trust (Paignton Zoo), Paignton, United Kingdom, ${ }^{3}$ Plymouth Electron Microscopy Centre, \\ University of Plymouth, Plymouth, United Kingdom
}

OPEN ACCESS

Edited by: Ben P. Harvey,

University of Tsukuba, Japan

Reviewed by:

Tomihiko Higuchi,

The University of Tokyo, Japan

Laura Ramajo,

Universidad Católica del Norte, Chile

*Correspondence:

Antony M. Knights

aknights@plymouth.ac.uk

Specialty section:

This article was submitted to Global Change and the Future Ocean,

a section of the journa Frontiers in Marine Science

Received: 29 May 2020 Accepted: 25 August 2020 Published: 08 October 2020

Citation:

Knights AM, Norton MJ, Lemasson AJ and Stephen N (2020)

Ocean Acidification Mitigates the Negative Effects of Increased Sea Temperatures on the Biomineralization and Crystalline Ultrastructure of Mytilus. Front. Mar. Sci. 7:567228. doi: 10.3389/fmars.2020.567228
Negative impacts of global climate change are predicted for a range of taxa. Projections predict marked increases in sea surface temperatures and ocean acidification (OA), arguably placing calcifying organisms at most risk. While detrimental impacts of environmental change on the growth and ultrastructure of bivalve mollusk shells have been shown, rapid and diel fluctuations in $\mathrm{pH}$ typical of coastal systems are often not considered. Mytilus edulis, an economically important marine calcifier vulnerable to climate change, were exposed to current and future OA (380 and $\left.1000 \mathrm{ppm} \mathrm{pCO}_{2}\right)$, warming $\left(17\right.$ and $20^{\circ} \mathrm{C}$ ), and ocean acidification and warming (OAW) scenarios in a seawater system incorporating natural fluctuations in $\mathrm{pH}$. Both macroscopic morphometrics (length, width, height, volume) and microscopic changes in the crystalline structure of shells (ultrastructure) using electron backscatter diffraction (EBSD) were measured over time. Increases in seawater temperature and OAW scenarios led to increased and decreased shell growth respectively and on marginal changes in cavity volumes. Shell crystal matrices became disordered shifting toward preferred alignment under elevated temperatures indicating restricted growth, whereas Mytilus grown under OAW scenarios maintained single crystal fabrics suggesting OA may ameliorate some of the negative consequences of temperature increases. However, both elevated temperature and OAW led to significant increases in crystal size (grain area and diameter) and misorientation frequencies, suggesting a propensity toward increased shell brittleness. Results suggest adult Mytilus may become more susceptible to biological determinants of survival in the future, altering ecosystem structure and functioning.

Keywords: multiple stressors, climate change, biomineralization, mussels, environmental variability, functioning

\section{INTRODUCTION}

Over the last century, atmospheric concentrations of $\mathrm{CO}_{2}$ have increased at an unprecedented rate resulting in changing environmental conditions on both land and sea. In the ocean, the increased absorption of $\mathrm{CO}_{2}$ due to higher atmospheric partial pressures is altering chemical reactions and driving declines in $\mathrm{pH}$ and $\left(\mathrm{CO}_{3}{ }^{2-}\right)$ (Doney et al., 2009) - a phenomenon referred to as ocean 
acidification (OA). At current $\mathrm{CO}_{2}$ emission rates, by 2100 atmospheric $\mathrm{CO}_{2}$ concentrations are predicted to exceed $1000 \mathrm{ppm}$ in some instances (Stocker et al., 2013), leading to reductions in $\mathrm{pH}$ of between 0.3 and 0.4 units from today's conditions (Doney et al., 2009). For marine life, changes in $\mathrm{pH}$ can have significant, detrimental effects on their structure and functioning (Lemasson et al., 2017a, 2018) including abnormal larval development (Kurihara et al., 2007; Kurihara, 2008), increased pressure on acid-base regulatory mechanisms (Lindinger et al., 1984; Thomsen and Melzner, 2010; Scanes et al., 2017) and changes to behavior (Queiros et al., 2015; Sadler et al., 2018).

For calcifying species, OA can be especially problematic due to disruption of the biomineralization process that is so crucial to the development of shells, exoskeletons and tests. In bivalve mollusks, the shell often consists of two polymorphs of calcium carbonate: the outer prismatic layer comprising calcite crystals, and the inner nacre layer comprising aragonite crystal tablets (Gazeau et al., 2013). Both polymorphs are formed within the extrapallial space following the catalytic conversion of $\mathrm{CO}_{2}$ to bicarbonate by the enzyme carbonic anhydrase (Marin and Luquet, 2004). This catalysis is a crucial process for calcium carbonate crystal nucleation, growth and orientation (Nakahara, 1991; Choi and Kim, 2000; Olson et al., 2013). Under normal conditions, these crystals are arranged as horizontal sheets (Checa et al., 2006; Hahn et al., 2012) but under predicted future climate conditions, crystal formation can become disordered and the crystals themselves misorientated or porous (Hahn et al., 2012; Fitzer et al., 2014a,b; Li et al., 2015; Meng et al., 2019; Figure 1). It is argued that these changes will have negative consequences for shell integrity and material properties (e.g., Beniash et al., 2010; Fitzer et al., 2015b), impacting the potential for mollusks to withstand physical and biological stress (Sadler et al., 2018).

The effects of $\mathrm{OA}$ on mollusk shell calcification and ultrastructure have largely been considered under fixed $\mathrm{pH}$ conditions; the experimental $\mathrm{pH}$ treatments are tightly controlled within a small pre-defined range and considerable negative consequences for organisms have been shown (e.g., Dupont et al., 2013). Yet increasingly, in situ measurements of $\mathrm{pH}$ in a range of coastal marine habitats including estuaries, kelp forests, coral reefs, and upwelling regions (Hofmann et al., 2011) reveal considerable natural fluctuations in $\mathrm{pH}$ (of up to 0.8 units) over short (diel) timescales (e.g., Lemasson et al., 2018). Where studies have incorporated $\mathrm{pH}$ fluctuations within their experiments either experimentally or by sampling organisms from sites with varying degrees of environmental fluctuation (Dufault et al., 2012; Comeau et al., 2014; Frieder et al., 2014; Ramajo et al., 2019), the impacts of OA have been less severe, perhaps due to transient exposure to less acidified conditions (Wahl et al., 2016) or that organisms originating from sites with naturally higher fluctuations in $\mathrm{pH}$ may be more tolerant or locally adapted to OA (Pansch et al., 2014).

Increasingly, studies are beginning to include the potential interactive effects of temperature in order to better simulate the ocean acidification and warming (OAW) environmental scenarios predicted for the end of the century. These studies have largely focused on macro-morphological change but often results appear contradictory or indicate a degree of context specificity (sensu Pansch et al., 2014); differences that may be driven by location, species, or life-history stage. For example, Lagos et al. (2016) found elevated temperatures mitigate negative impacts of OA on shell growth in Argopecten purpuratus. In Littorina littorea, Melatunan et al. (2013) found elevated temperature or reduced $\mathrm{pH}$ were equally detrimental to growth but effects increased in severity when combined, and Lemasson et al. (2018) found elevated temperature but not OA affected growth in oysters.

Relatively few studies have assessed the combined effects of OAW scenarios on shell ultrastructure. Independently, temperature has been shown to induce significant crystal misorientation (Olson et al., 2013), changes in thickness (Olson and Gilbert, 2012; Gilbert et al., 2017) and alteration in the overall ultrastructure (Füllenbach et al., 2014). These studies, however, have mainly been in the context of paleo-environmental proxies which arguably have limited relevance to the current, rapid changes in temperature driven by anthropogenic activities. Of the studies that have investigated the combined effects of OA and warming (e.g., Fitzer et al., 2014b, 2015b; Li et al., 2015), the evidence suggests that elevated temperatures can exacerbate ultrastructure disruption caused by elevated $\mathrm{pCO}_{2}$, although the chosen experimental conditions are not necessarily those marine organisms are expected to face in the next century.

Understanding change in the morphological characteristics of shell ultrastructure, such as changes in crystal orientation, the occurrence of coincident site lattice (CSL) boundaries between crystals, and crystal size, may provide important insights in to how organisms will respond to future climate change. Misorientation - the difference in orientation between adjacent crystals - is expected to be relatively rare under low stress conditions as the organic matrix is able to maintain a well-ordered ultrastructure. Under environmental stress (e.g., OAW scenarios), that organic matrix may breakdown leading to disordered ultrastructure and higher instances of crystal misorientation (Olson et al., 2013). Crystal misorientation can lead to an increased frequency of CSL boundaries; the boundary where the positions of a proportion of lattice sites coincide at the boundary segments between two adjacent crystals (Fortes, 1972). Some material science studies have found that low angle grain boundaries and low Sigma $(\Sigma)$-value CSL boundaries can influence material properties with increases in hardness and resistance to the spread of intergranular cracks (Lehockey et al., 2004; Arafin and Szpunar, 2009). An increased frequency of certain CSL boundaries in biomineralized structures such as calcified mollusk shells, may be an important determinant of resistance to mechanical stresses like those experienced by bivalves under predation pressure from decapods and gastropods (Elner, 1978; Sadler et al., 2018). Changes in crystal size may also indicate impacts of environmental conditions on crystal nucleation and growth 

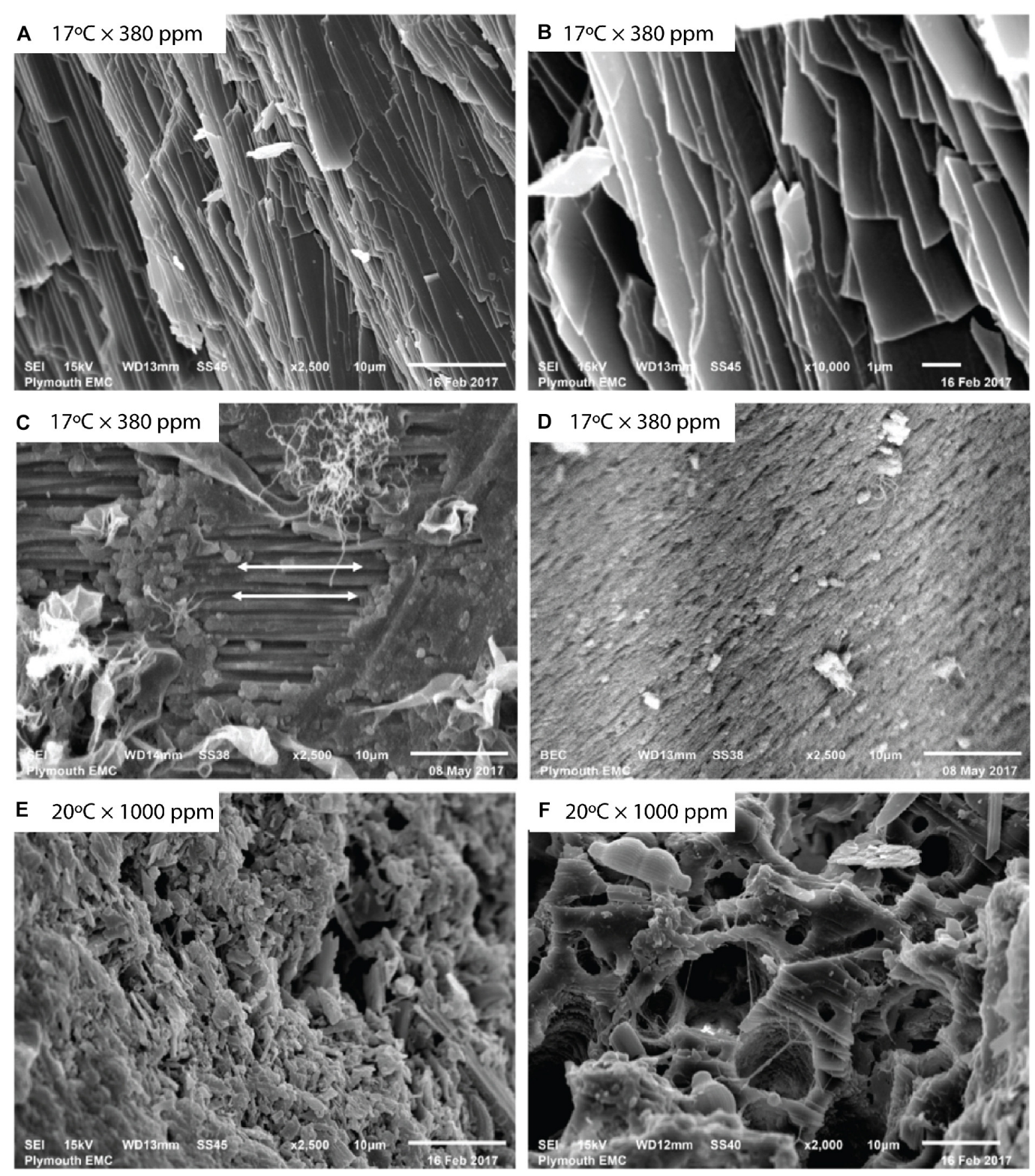

FIGURE 1 | Mytilus sp. valves imaged using backscattered electron (BSE) imaging. Unprepared baseline Mytilus (A,B) show naturally occurring aligned crystalline structures at (A) 2500x, and (B) 10,000 x magnification before specimen preparation. Prepared baseline specimens (C,D) at 2500 x magnification reveal differences in prismatic and nacre layers showing (C) aligned crystalline structure as indicated by arrows, and (D) more porous structure with lack of an observable regular crystalline alignment. Mytilus exposed to elevated temperature and $\mathrm{pCO}_{2}(\mathbf{E}, \mathbf{F})$ show $(\mathbf{E})$ disrupted, irregular structure, and $(\mathbf{F})$ a fragmented, porous nature.

mechanisms. Such changes have been shown over paleogeological timescales (e.g., Olson and Gilbert, 2012; Gilbert et al., 2017) but have yet to be considered in the context of rapid environmental change that marine organisms are experiencing today.

This study investigated the extent to which the combination of elevated $\mathrm{pCO}_{2}$ concentrations and temperature can alter the growth and ultrastructure of Mytilus sp. Using an experimental mesocosm system able to replicate future OAW scenarios that encompasses natural fluctuations in $\mathrm{pH}$, we compare changes in (i) whole organism shell growth, and (ii) crystal orientation, size, and lattice boundary formations using cutting-edge electron backscatter diffraction techniques (EBSD).

\section{MATERIALS AND METHODS}

\section{Mussel Culture}

Mussels were collected from Queen Anne's Battery, Plymouth $\left(50^{\circ} 36^{\prime} 40.82^{\prime \prime} \mathrm{N}, 4^{\circ} 13^{\prime} 11.61^{\prime \prime} \mathrm{W}\right)$, cleared of epibionts with a metal scraper, and transported back to the lab in buckets 
of seawater. Animals were placed in tanks containing UVtreated filtered seawater collected from the sampling location within $1 \mathrm{~h}$ of collection and allowed to acclimate to laboratory conditions (salinity $-29.7 \pm 2.3$; temperature $-17^{\circ} \mathrm{C} \pm 0.20$; $\mathrm{pH} 8.00 \pm 0.04)$ for 2 weeks. After acclimation, 36 mussels were randomly allocated to 12 chambers ( 3 mussels per chamber) for 8-week. These chambers were filled with fresh UV-treated filtered sea water, also collected from the sampling location. Mean salinity was marginally higher (32.6 \pm 1.3$)$ than in the acclimation treatment as a result of natural fluctuations in salinity due to rainfall and riverine inputs. Each chamber represented one of four environmental scenarios $(n=3)$. By the end of the century, future climate change scenarios predict increases in sea surface temperature of $2-4^{\circ} \mathrm{C}$ and increases in atmospheric $\mathrm{pCO}_{2}$ of $\sim 600-800 \mathrm{ppm}$ (IPCC, 2014) depending on the emissions (RCP) scenario. Here, we adopted a temperature increase of $3^{\circ} \mathrm{C}$ and $\mathrm{pCO}_{2}$ increase of $620 \mathrm{ppm}$, resulting in the following four combinations: (1) $17^{\circ} \mathrm{C} \times 380 \mathrm{ppm} \mathrm{pCO}_{2}$; (2) $17^{\circ} \mathrm{C} \times 1000 \mathrm{ppm} \mathrm{pCO}_{2}$; (3) $20^{\circ} \mathrm{C} \times 380 \mathrm{ppm} \mathrm{pCO}_{2}$; and (4) $20^{\circ} \mathrm{C} \times 1000 \mathrm{ppm} \mathrm{pCO}_{2}$. Temperature treatments were maintained using recirculating thermostatically controlled heated water baths (Aqua Medic, United Kingdom) bubbled with air or 1000 ppm $\mathrm{CO}_{2}$-enriched air (see Lemasson et al., 2018). $\mathrm{CO}_{2}$ concentrations were controlled using a $\mathrm{CO}_{2}$ gas analyzer (LI-COR LI-820, United States). Natural fluctuations in $\mathrm{pH}$ result from this approach as $\mathrm{pCO}_{2}$ concentrations remain static and $\mathrm{pH}$ changes occur as a result of fluctuations in atmospheric pressure, although these fluctuations in $\mathrm{pH}$ were relatively small with a maximum standard deviation of $0.1 \mathrm{pH}$ units in any treatment (Supplementary Table S1). Seawater $\mathrm{pH}$ (SevenExcellence Multi-parameter $\mathrm{pH}$ probe), temperature (Omega HH802U temperature probe) and salinity (HI96822 Seawater Refractometer) were tested daily and total alkalinity (TitraLab@ AT1000 series workstation) and pCO $_{2}$ (Corning 965 $\mathrm{TCO}_{2}$ Analyser) were measured three times per week. Mussels were fed every other day with $10 \mathrm{~mL}$ of Shellfish Diet 1800 at a concentration of $\sim 4500$ cell $\mathrm{mL}^{-1}$ (Thomsen and Melzner, 2010; Fitzer et al., 2014b). Four biometric parameters: total wet mass, shell length, shell width, and shell height were measured before and after an 8-week exposure period.

Body volume $\left(\mathrm{cm}^{3}\right)$ of all individuals $(N=36)$ was calculated using the volume of water displaced $(\mathrm{mL})$ by the mussel in a volumetric cylinder containing sea water (density of $1.025 \mathrm{~g} / \mathrm{cm}^{3}$ at $20^{\circ} \mathrm{C}$, salinity $\left.=35\right)$. This approach controls for any water retained within the mantle. Displacement $(\mathrm{mL})$ of an individual was measured at time zero $\left(t_{0}\right)$ and after 8 -week $\left(t_{8}\right)$ of exposure to all experimental treatments. Sea water density was measured using a hand-held digital refractometer $(D \& D$, The Aquarium Solution Ltd., United Kingdom). Shell dimensions (length, width, height) were measured using digital calipers (Mitutoyo, Japan) to the nearest $0.1 \mathrm{~mm}$, also at $t_{0}$ and $t_{8}$ (Figure 2A).

\section{Ultrastructure Data Sampling Procedure}

After 8-week, all mussels were euthanized and the soft tissue removed. Two mussels per treatment were randomly chosen from the control $\left(17^{\circ} \mathrm{C} \times 380 \mathrm{ppm} \mathrm{pCO}_{2}\right)$, elevated temperature $\left(20^{\circ} \mathrm{C} \times 380 \mathrm{ppm} \mathrm{pCO}_{2}\right)$, and elevated temperature and $\mathrm{pCO}_{2}$ treatment $\left(20^{\circ} \mathrm{C} \times 1000 \mathrm{ppm} \mathrm{pCO}_{2}\right)$ and a cross-section from the lip area of each mussel removed using a high-speed cutting wheel (Dremel, United States). Mussels from a control temperature and elevated $\mathrm{pCO} 2$ treatment $\left(17^{\circ} \mathrm{C} \times 1000 \mathrm{ppm} \mathrm{pCO}_{2}\right)$ were not used for EBSD analysis due to logistical constraints and given that this scenario is not expected under future climate scenarios. Cross-sectional cuts were specifically made to allow examination of the ultrastructure between the prismatic and nacre layers (Figure 2B) along the growth direction in the most recently formed shell material (Checa et al., 2006; Hahn et al., 2012).

Shell samples were mounted in epoxy resin (Struers Epofix), ground [Buehler Carbimet Grit ${ }^{\mathrm{TM}} 600$ (P1200) pad] and sequentially polished with $6 \mu \mathrm{m}$ then $1 \mu \mathrm{m}$ diamond suspensions (Buehler MetaDi ${ }^{\circledR}$ ) until a glossy appearance was achieved. Samples were then polished using a vibratory polisher (Buehler VibroMet2 ${ }^{\circledR}$ ) with a $0.05 \mu \mathrm{m}$ polishing suspension (MasterPrep ${ }^{\mathrm{TM}}$ ) diluted in distilled water. Samples were examined under an optical microscope (Meiji Techno EMZ-13TR, Infinity 1) to check the quality of the polished surface (Figure 1). Samples were preserved in ethanol before carbon sputter-coating (Quorum Technologies Q150T ES, United Kingdom).

Samples were examined in a variable-pressure scanning electron microscope (SEM) (JEOL 6610 VP-SEM, Japan) under high vacuum at $15 \mathrm{kV}$. Magnification, spot size, and working distance were modified between samples to optimize data acquisition. Crystallographic data were obtained using a Nordlys Nano EBSD detector with AZtec software, and analyzed using HKL CHANNEL5 post-processing software (Oxford Instruments, United Kingdom). Grains were detected using a minimum pixel number of 10 (default setting) and a critical misorientation angle of $3^{\circ}$ as the defining criteria (Goetz et al., 2011).

\section{Ultrastructure Parameters}

Differences in the ultrastructure between samples were assessed using a combination of inverse pole figure (IPF) orientation maps, contoured pole figures, frequency distributions of grain boundary misorientation angles, $\Sigma$-value CSL boundaries, grain area, and grain diameter metrics. IPF maps using the $z$-direction (IPFz; perpendicular to the sample surface) as the sample reference direction were used to demonstrate patterns of variability in orientation in shell samples. IPF maps present patterns of crystallographic orientation using different colors to illustrate different orientations of EBSD measurement pixels relative to a fixed orientation. In a well-ordered ultrastructure, IPF maps would be expected to show similar orientations throughout much of the mapped site, or with different orientations restricted to definable regions. The majority of grains should appear to face a similar direction along the sample surface. In a more disordered ultrastructure, the mapped sites would be expected to show a wide variation in orientation with the direction that the grains face, relative to the sample surface, appearing more random.

Contoured pole figures ( 1 point per grain analysis) were used to demonstrate the variation in crystallographic orientation of individual grains relative to different planes. Ordered/orientated 

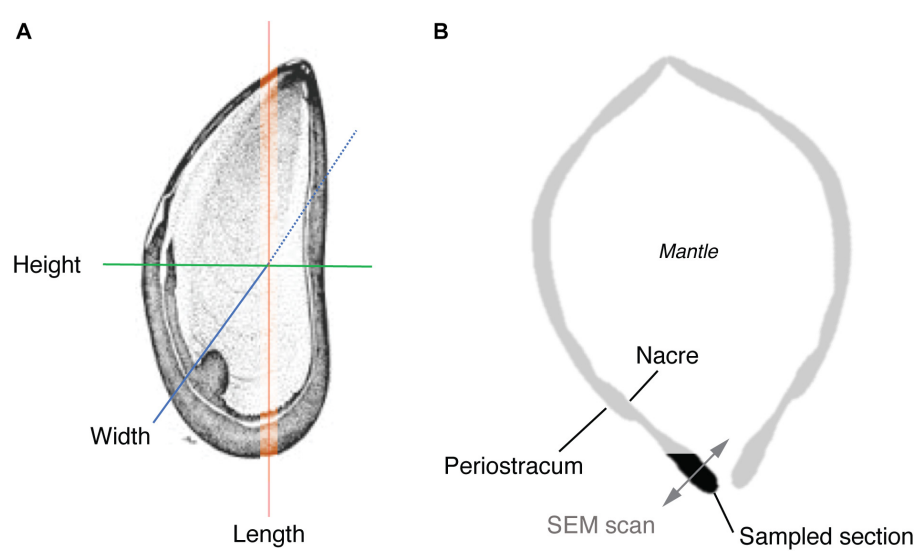

FIGURE 2 | Schematic illustrating (A) dimensional features (excluding volume) measured in the macro-morphometric study, and (B) transverse section of a mussel showing the location of the shell section used in EBSD analysis and direction of EBSD scans.

crystal lattices form clusters around specific orientations (i.e., single crystal fabrics), which indicates uninhibited growth, whereas disordered/misorientated crystal lattices demonstrate "preferred alignment" indicating inhibited growth. The probability of grain orientation angles (multiple uniform densities; MUD) are illustrated using pole figures.

The frequency distribution of grain boundary misorientation angles demonstrates variation in co-orientation between adjacent grains. Misorientation angle is defined as the rotation angle required to map the lattice of the boundary segment of a grain to the lattice of the adjacent boundary segment (Oxford Instruments, 2015) and the frequency distributions of the $\Sigma$ values of CSL boundaries can demonstrate variation in coorientation and fracture resistance between grains. The $\Sigma$ values reflect the proportion of coincident lattice sites between the two boundary segments. For example, in $\Sigma 3$ boundaries, one out of every three lattice sites are coincident between the boundary segments (Fortes, 1972). IPFz maps were annotated with the positions of grain and CSL boundaries to demonstrate the distribution of different misorientation angle ranges and $\Sigma$ values, respectively.

Grain size was used to test for changes in grain formation and growth. Both grain area and diameter were included as measures of grain size, and plotted as frequency distributions, to account for the potential effect of grain shape on the latter.

Three regions (subsets) were defined for each treatment to further explore the variability in ultrastructure parameters within a single shell sample. Each region was chosen to assess crystalline structure in the outer periostracum layer (subset 1), center (subset 2 ), and inner nacre layer (subset 3 ) to determine if different regions of the shell responded differently to environmental stresses (Figure 2B shows the transverse EBSD scan direction). Statistical tests were only conducted between subsets from the same sample.

\section{Data and Statistical Analysis}

Changes in growth and body volume were analyzed using a three-factor linear mixed-effects model to test for significant changes in body volume and growth over time in response to temperature $\left(17\right.$ and $20^{\circ} \mathrm{C}$ ) and $\mathrm{pCO}_{2}(380$ and $1000 \mathrm{ppm})$ concentration. Temperature and $\mathrm{pCO}_{2}$ were included as fixed factors, and "individual" was included as a random factor to account for potential differences in intra-individual responses to experimental conditions within each tank. Model reduction was performed to test for the effect of the random factor, using Akaike information criterion (AIC) to test for significance differences between the maximum (including the random variable) and reduced (excluding the random variable) model predictive power. In all analyses, there was no significant increase in AIC indicating no difference in response among individuals.

Differences in grain boundary misorientation angles, $\Sigma$-value of CSL boundaries, grain orientation angle (from pole plots), grain area and grain diameter were compared using planned pairwise Kolmogorov-Smirnov tests to compare frequency distributions (Sokal and Rohlf, 1995). All statistical tests were performed in the open source software, $\mathrm{R}$ ( $\mathrm{R}$ Development Core Team, 2017) and the package "nlme" (Pinheiro et al., 2020).

\section{RESULTS}

\section{Mussel Volume and Growth}

There were significant changes in body volume depending on temperature and $\mathrm{pCO}_{2}$ conditions after 8-week $\left(F_{1,32}=11.9\right.$, $p<0.01)$. Mussel body volume reduced under either elevated temperature $\left(20^{\circ} \mathrm{C}\right)$ or $\mathrm{pCO}_{2}(1000 \mathrm{ppm})$, but marginally increased under control $(0.13 \pm 0.09 \mathrm{~mL})$ and elevated temperature and $\mathrm{pCO}_{2}$ conditions $(0.05 \pm 0.02 \mathrm{~mL})$ (Figure 3).

There were significant reductions in both shell width and length under the $\mathrm{OAW}$ scenario $\left(20^{\circ} \mathrm{C} \times 1000 \mathrm{ppm}\right.$; width: $F_{1,32}=9.2, p<0.01$; length: $\left.F_{1,32}=5.6, p<0.05\right)$ of $1.05 \pm 0.48 \mathrm{~mm}$ and $0.86 \pm 0.44 \mathrm{~mm}$, respectively. There was no change in morphometrics under control $\left(17^{\circ} \mathrm{C} \times 380 \mathrm{ppm}\right)$, increased temperature or increased $\mathrm{pCO}_{2}$ conditions (Figures 3B,C). There was no significant change in shell height among treatments $\left(F_{1,32}=0.56, n s\right.$, Figure 3D), although trends suggest a decrease in shell height especially 


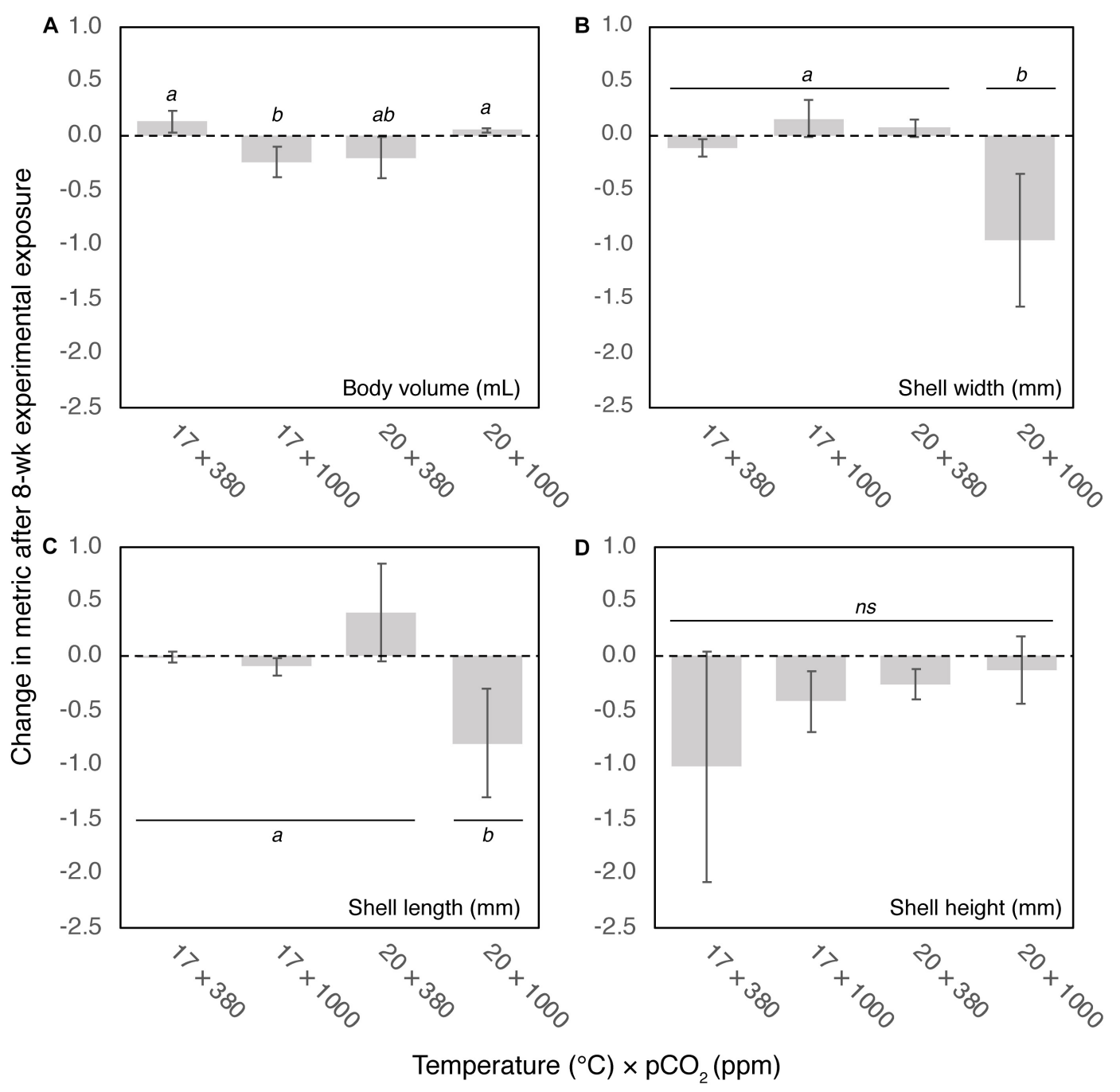

FIGURE 3 | Change in (A) body volume ( $\mathrm{mL})$, (B) shell width $(\mathrm{mm})$, (C) length $(\mathrm{mm})$, and (D) height $(\mathrm{mm})$ after 8-week exposure to four climate scenarios. Error bars show standard error. Results of post hoc pairwise comparisons are shown, where shared letters indicate no significant difference between pairwise groups $(p>0.05)$, and different letters indicate significant differences $(p<0.05)$ between pairwise groups.

under control conditions, albeit reduction among individuals being highly variable.

\section{Ultrastructure Parameters \\ Grain Area and Diameter}

There were significant differences in the frequency distributions of grain areas and diameters among all experimental treatments after 8-week (Kolmogorov-Smirnov paired comparisons; $p<0.001$ for all comparisons). Both grain area and diameters tended toward smaller dimensions (left skew; Figure 4). Grain areas and diameters were smallest in the control treatment $\left(17^{\circ} \mathrm{C} \times 380 \mathrm{ppm}\right)$, largest in the elevated temperature treatment $\left(20^{\circ} \mathrm{C} \times 380 \mathrm{ppm}\right)$, and of intermediate size in the OAW $\left(20^{\circ} \mathrm{C} \times 1000 \mathrm{ppm}\right)$ treatment. Median grain areas were $3.6 \times$ and $2.2 \times$ larger, and diameters $1.9 \times$ and $1.5 \times$ larger, in $20^{\circ} \mathrm{C} \times 380 \mathrm{ppm}$ and $20^{\circ} \mathrm{C} \times 1000 \mathrm{ppm}$ treatments respectively than in the control treatment (Figure 4). While median grain area was lower in the OAW scenario than the temperature only treatment, the maximum grain area observed in mussels from the OAW treatment was up to $7.8 \times$ larger $\left(12,887 \mu \mathrm{m}^{2}\right.$ vs. $\left.1680 \mu \mathrm{m}^{2}\right)$ and $16.5 \times$ larger than the temperature only $\left(20^{\circ} \mathrm{C} \times 380 \mathrm{ppm}\right)$ and control treatments, respectively (Figure 4).

\section{Crystallographic Orientation and Disorientation}

Change in crystallographic orientation and increased prevalence of misorientation angles were revealed by EBSD (Figure 5). Under control conditions, crystal orientation was largely wellordered with clear evidence of single crystal fabrics (uninhibited growth) across all crystal planes (Figure 6). There were few deviations from the expected crystallographic orientation angle of $3-10^{\circ}$ and a low prevalence of high misorientation angles $\left(16 \%>20^{\circ}\right)$. Under elevated temperature $\left(20^{\circ} \mathrm{C} \times 380 \mathrm{ppm}\right)$ 


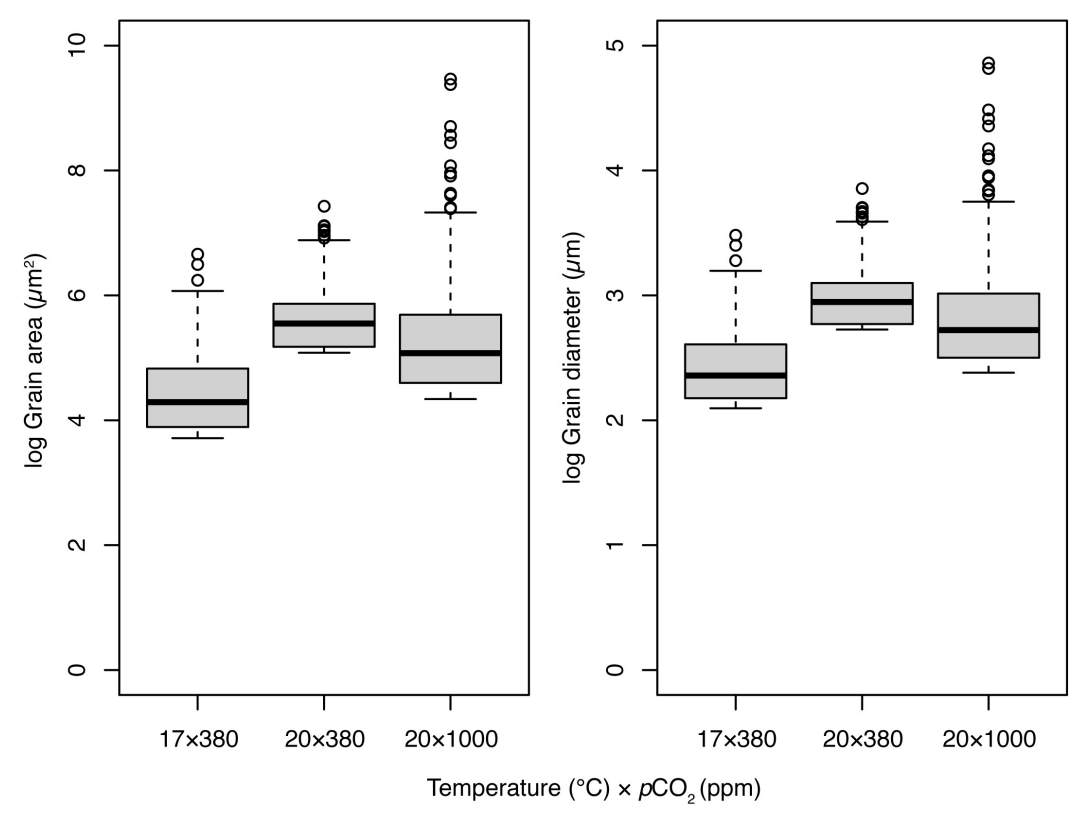

FIGURE 4 | Distribution of grain areas $\left(\mu \mathrm{m}^{2}\right)$ and diameters $(\mu \mathrm{m})$ within regional subsets of Mytilus sp. exposed to three temperature $\left({ }^{\circ} \mathrm{C}\right)$ and $\mathrm{pCO} 2$ climate scenarios for 8-week. Thick lines of boxplots represent the median value, hinge lengths (end of box) represent the 25 and $75 \%$ quartiles from the median, and whiskers represent the 1.5 times the interquartile range (IQR) beyond the hinge. Outliers are shown as black circles.

and $\mathrm{OAW}\left(20^{\circ} \times 1000 \mathrm{ppm}\right)$ scenarios, crystals along the 0001 plane also showed propensity toward single crystal fabrics; the orientation of the crystals in the elevated temperature scenario were also rotated.

The 11-20 and 10-10 planes of the elevated temperature treatment exhibited a major shift toward preferred alignment and a higher prevalence $(\sim 23.1 \%)$ of misorientated angles $\left(>20^{\circ}\right)$ at the grain boundaries (Kolmogorov-Smirnov tests, $p<0.01$; Figures 5, 6). This shift toward larger misorientation angles $\left(>20^{\circ}\right)$ was even more apparent in the OAW-treated mussels (41\%), although crystals appeared to continue to grow as a single crystal fabric in all planes (Figure 6).

Comparison of growth between the external-facing (prismatic) layer and internal-facing (nacreous) revealed differing responses to changed environmental conditions. Focusing on the 11-20 plane only (although a similar pattern was also apparent in the 10-10 plane), Mytilus reared in elevated temperatures only $\left(20^{\circ} \mathrm{C} \times 380 \mathrm{ppm}\right)$ showed evidence of restricted growth (preferred alignment) across the entire transverse section of the shell, in particular, within the nacreous region (Figure $\mathbf{7 H}$ ). In comparison, Mytilus sp. grown under control (Figurse 7A,D,G) and OAW conditions continued to demonstrate single crystal fabric (uninhibited) growth, if not, with marginally lower "intensity" (Figures 7C,F,I).

\section{Coincident Site Lattice Boundaries}

Coincident site lattice boundaries were most frequent in the elevated temperature treatment $\left(20^{\circ} \mathrm{C} \times 380 \mathrm{ppm}\right)$ followed by the OAW scenario and then the control treatment (Figures 5B,D,F). CSL boundaries in the OAW and control samples were restricted to isolated patches, whereas under elevated temperature only, CSL boundaries were distributed throughout the region, although there was no significant difference in the occurrence of these boundaries among treatments.

\section{DISCUSSION}

By the end of the century, future climate change scenarios predict increases in sea surface temperature of $\sim 4^{\circ} \mathrm{C}$ and increases in atmospheric $\mathrm{pCO}_{2}$ of $\sim 600-800 \mathrm{ppm}$ (IPCC, 2014). Exposure of the commercially valuable mussel species, Mytilus, to conditions predicted for 2100 led to changes in body volume and shell growth at the macroscale, and alteration of shell crystallization (ultrastructure) at the microscale, although negative consequences mostly occurred under temperature as a single stressor rather than in combination with increases in $\mathrm{pCO}_{2}$. Results suggest an antagonistic relationship between temperature and $\mathrm{pCO}_{2}$ stressors on biological functioning of Mytilus.

Body volume was reduced under elevated temperature or elevated $\mathrm{pCO}_{2}$ treatments, but marginally increased under control conditions or when both temperature and $\mathrm{pCO}_{2}$ were elevated. In contrast, shell length and width reduced under elevated temperature and $\mathrm{pCO}_{2}\left(20^{\circ} \mathrm{C} \times 1000 \mathrm{ppm}\right)$ conditions, but marginally increased under elevated temperatures $\left(20^{\circ} \mathrm{C}\right)$ only. Body volume can act as a proxy measure for the condition of the mussel; change in the mass of soft tissue filling the mantle alters the shell: tissue: mantle-volume ratio and thus water displacement, thereby indicating change in energy utilization over time in somatic tissues development 

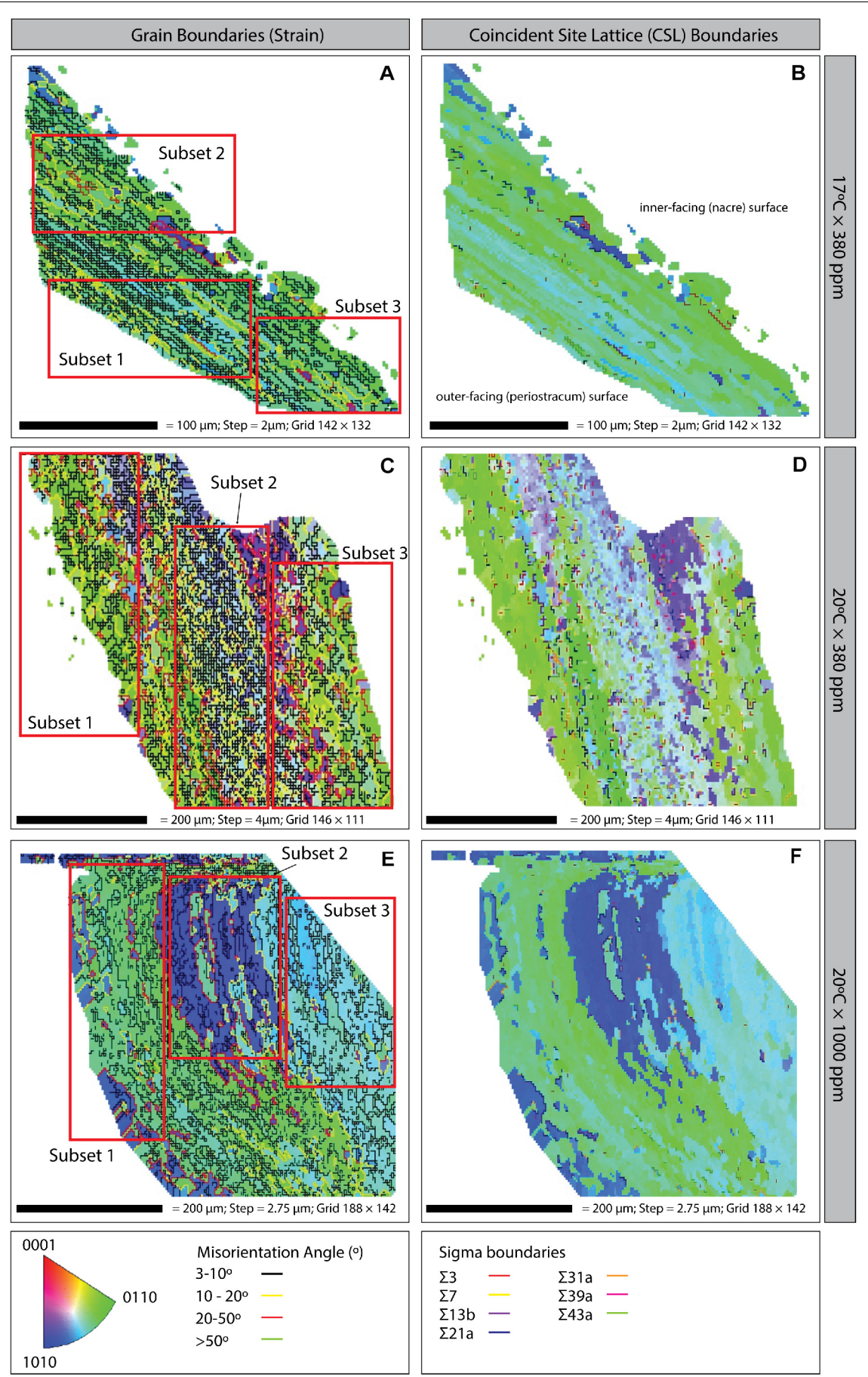

FIGURE 5 | Inverse pole figure (IPF) maps with grain boundaries (left column) and coincident site lattice (CSL; right column) boundaries of Mytilus sp. shell samples grown under three climate scenarios: (A,B) $17^{\circ} \mathrm{C} \times 380 \mathrm{ppm}\left(\right.$ Control); (C,D) $20^{\circ} \mathrm{C} \times 380 \mathrm{ppm}$ (Ocean warming without acidification); and (E,F) $20^{\circ} \mathrm{C} \times 1000 \mathrm{ppm}$ (Ocean warming with acidification). Bottom: Crystal orientation color inset key; grain boundary misorientation (strain) angles; and CSL Sigma boundaries (right column). All plots are orientated in the same way i.e., the left-hand side of the image is the outer-facing periostracum surface and the right-hand side is the inner-facing (nacre) surface (as illustrated on panel B).

or maintenance (e.g., Melzner et al., 2011; Huning et al., 2013). The reductions in volume associated with elevated water temperature or $\mathrm{pCO}_{2}$ might initially suggest an increased metabolic cost to individuals preventing soft issue maintenance, but concurrent increases in shell width and length instead suggest a reallocation of energy toward shell maintenance 

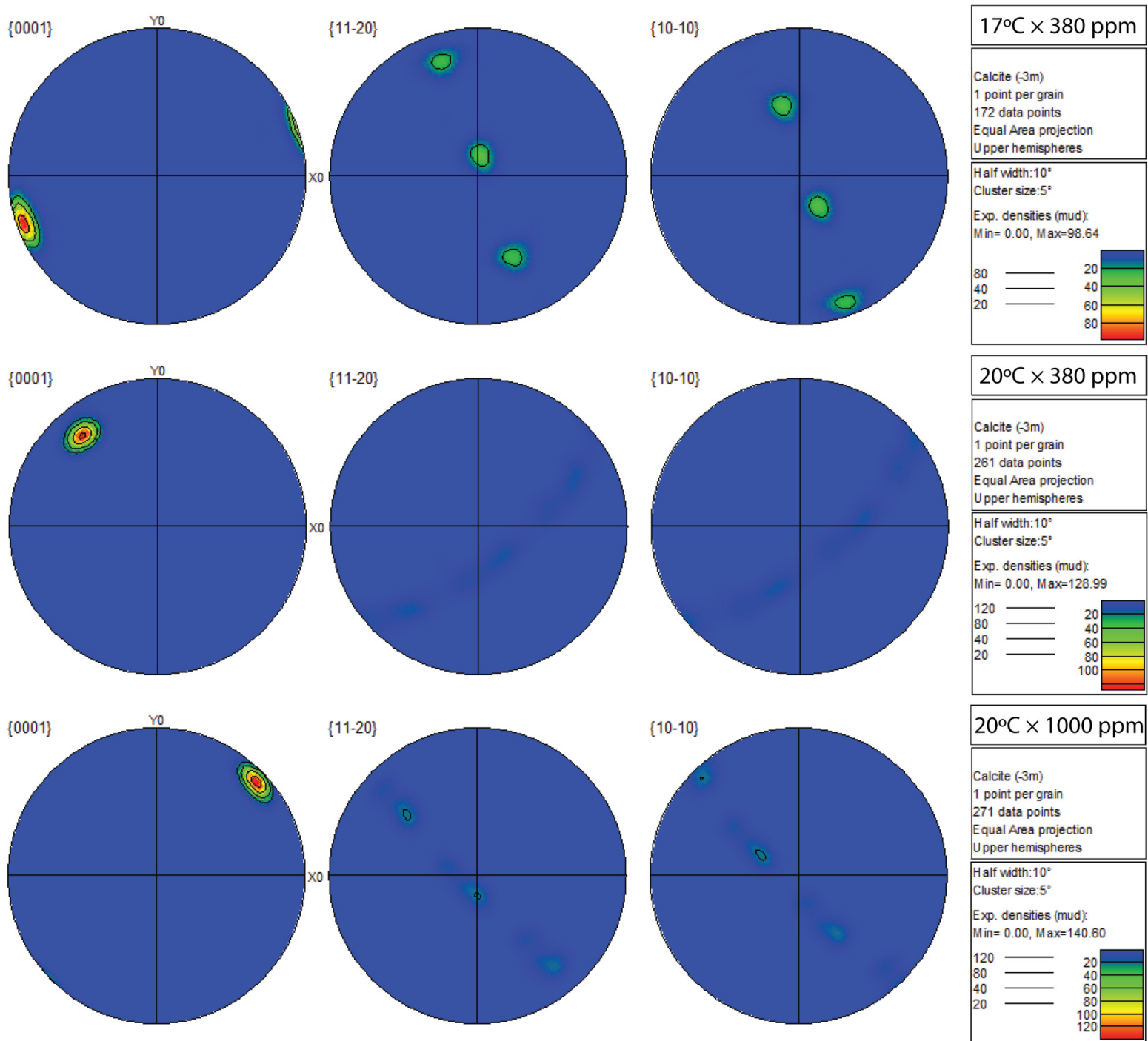

FIGURE 6 | Contoured pole figures (1 point per grain analysis) showing variation in crystallographic orientation along three crystal planes (0001; 11-20; 10-10) in Mytilus sp. grown for 8-week under three climate scenarios (top: $17^{\circ} \mathrm{C} \times 380 \mathrm{ppm}$; middle: $20^{\circ} \mathrm{C} \times 380 \mathrm{ppm}$; bottom: $20^{\circ} \mathrm{C} \times 1000 \mathrm{ppm}$ ). The clear single-crystal fabric observed in the control data (top row) becomes more diffuse along both short axes $(\{11-20\}$ and $\{10-10\})$ as temperature $\left(20^{\circ} \mathrm{C} \times 380 \mathrm{ppm}\right)$, or temperature and $\mathrm{CO}_{2}\left(20^{\circ} \mathrm{C} \times 1000 \mathrm{ppm}\right)$ increases.

under these single stressor conditions. Previous studies have shown organisms can induce shell thickening (Bibby et al., 2007; Melatunan et al., 2013) or repair damage to their shells (Coleman et al., 2014) through reallocation of energy to specific physiological processes, although OAW scenarios can alter this response. For instance, Li et al. (2016) showed that OAW implemented a compensatory acid-base mechanism, metabolic depression, and up-regulation of physiological responses leading to change in calcification rates, the calcium and carbon content within shells, as well as change in shell ultrastructure. Here, the notable decreases in shell length and width under the elevated temperature and $\mathrm{pCO}_{2}\left(20^{\circ} \mathrm{C} \times 1000 \mathrm{ppm}\right)$ scenario support these previous findings, suggesting depression of some energetically expensive processes (i.e., soft tissue maintenance) and up-regulation of other physiological and biochemical functions. The observed increases in shell length and width under elevated $\mathrm{pCO}_{2}$ and ambient temperature conditions $\left(17^{\circ} \mathrm{C} \times 1000 \mathrm{ppm}\right)$ also suggests that mussels may have some capacity to up-regulate biomineralization to maintain or grow shell material under OA (Bibby et al., 2007; Melatunan et al., 2013; Coleman et al., 2014, but see Leung et al., 2020); a process that may be driven by an up-regulation of ion and proton transport genes associated with organic matrix formation (Glazier et al., 2020).

There were also changes in the ultrastructure of mussels grown under future climate conditions. Under elevated temperature, the shell ultrastructure became disordered shifting from single crystal fabrics toward preferred alignment suggesting "restricted" 


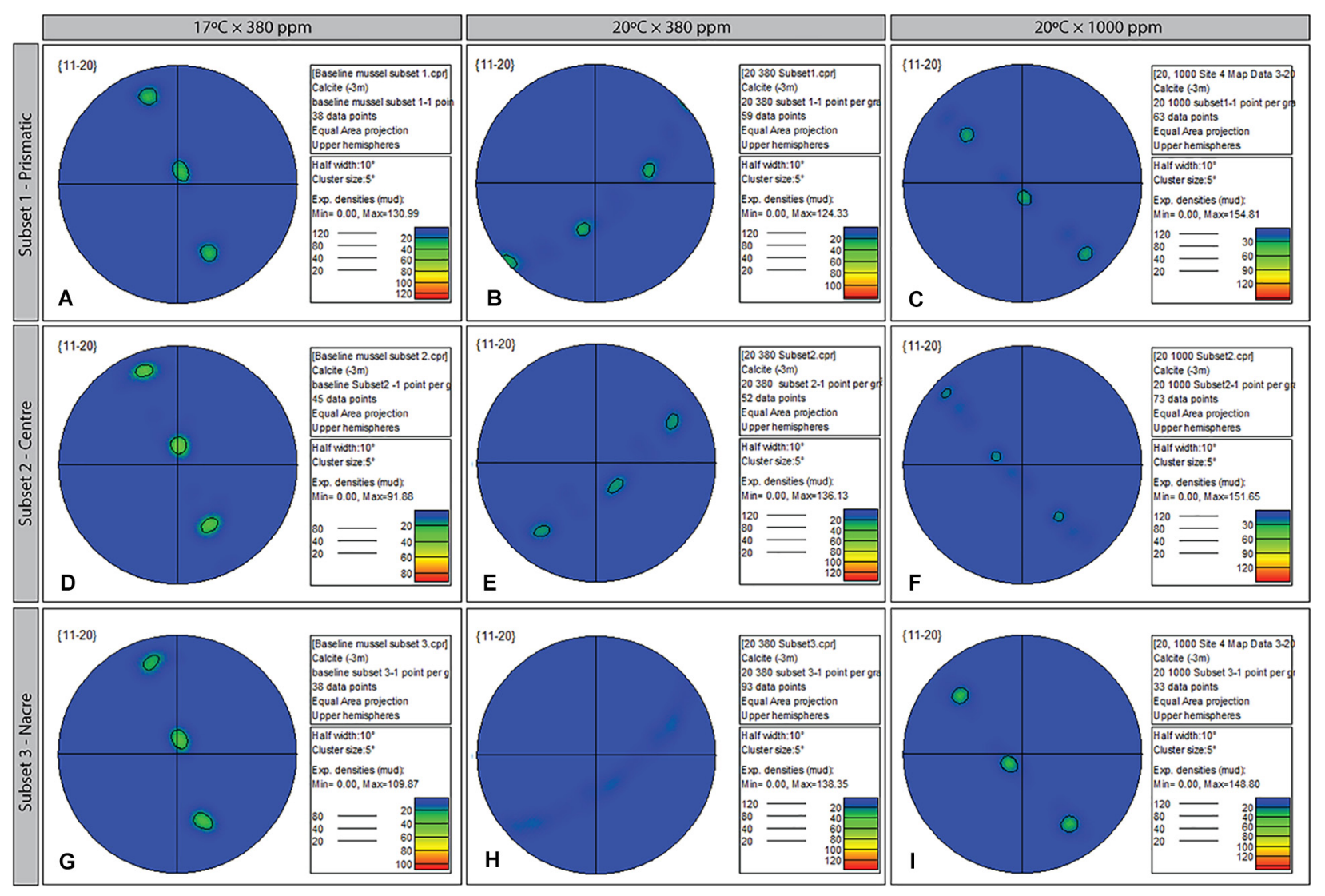

FIGURE 7 | Contoured pole figures (1 point per grain analysis) showing variation in crystallographic orientation along the 11-20 crystal plane in three regions (prismatic; center; and nacreous layers) of the ultrastructure of Mytilus sp. grown for 8-week under three climate scenarios: Control (A,D,C); Elevated Temperature $\mathbf{( B , E , H )}$; and Elevated Temperature and $\mathrm{pCO}_{2} \mathbf{( C , F , I ) . ~ T h e ~ M U D ~ v a l u e ~ f o r ~ t h e ~ t h r e e ~ t r e a t m e n t s ~ v a r i e s ~ f r o m ~} 98.64$ (baseline, $\left.17 \times 380\right)$ to 154.81 (subset 1 , $20 \times 1000)$

growth, whilst area and diameter of individual grains became significantly larger. In contrast, under elevated temperature and $\mathrm{pCO}_{2}$, crystalline structures remained ordered as a single crystal fabric, in the same way as control mussels, suggesting OA conditions may be mitigating the effect of temperature. Both future scenarios led to increased frequencies of crystal misorientation; an indicator of stress that signifies the formation of microcracks and weakening of the shell. Previous studies have shown bivalves grown under increasing $\mathrm{pCO}_{2}$ produce a stiffer, harder calcite (prismatic) layer that is more brittle, whereas the aragonite (nacre) layer may become less stiff and softer (Beniash et al., 2010; Fitzer et al., 2015a) but see Hiebenthal et al. (2013), Mackenzie et al. (2014). While not tested here, the elongation of the crystals grown under elevated temperature and $\mathrm{OA}\left(20^{\circ} \mathrm{C} \times 1000 \mathrm{ppm}\right)$ suggests greater crystal malleability, not just within the nacre region of the shell but across the entire transverse section of the shell. Our results are therefore, in part, contradictory to previous studies that have reported disordered shell ultrastructure under elevated $\mathrm{pCO}_{2}$ in Mytilus (Hahn et al., 2012; Fitzer et al., 2014a,b, 2016) and other mollusks (Beniash et al., 2010); an effect argued to be further exacerbated under elevated temperature (Fitzer et al., 2014b). It should be noted, however, that our experimental future climate temperatures $\left(20^{\circ} \mathrm{C}\right)$ were considerably higher than those used in Fitzer et al. (2014b).

Change in the physiological mechanisms that underpins ultrastructure composition remain poorly understood (Li et al., 2016). A link between ultrastructure disruption and reduced expression of calcification proteins under elevated $\mathrm{pCO}_{2}$ has been proposed (e.g., Huning et al., 2013; Fitzer et al., 2014b), although shell matrix protein candidate genes and the expression of carbonic anhydrase - the latter of which catalyzes the interconversion of bicarbonate and $\mathrm{CO}_{2}$ - appear less affected by elevated $\mathrm{CO}_{2}$ (Huning et al., 2013). Furthermore, our understanding of the interaction between protein expression, functioning, and $\mathrm{CaCO}_{3}$ formation remains limited (see Glazier et al., 2020 for a recent study in corals). A number of models have been proposed including: changes in epitaxial growth, the formation of "mineral bridges" between crystals, or alteration of the $c$-axis (0001 plane) orientation during the earlier stages of crystal formation (Choi and Kim, 2000; Checa et al., 2006; Fryda et al., 2010; Olson et al., 2013; Maier et al., 2014). Clarification of changes in the physiological mechanisms including gene functioning and regulation under future climate scenarios may 
shed light on the capacity of marine species, and especially calcifiers, to mitigate the effects of environmental change.

Our mesocosm system uses fixed input concentrations of $\mathrm{CO}_{2}$ and we do not attempt to modify these concentrations using feedback loops to control (fix) $\mathrm{pH}$. Consequently, the ocean chemistry in our test system behaves in the same way as in situ seawater would i.e., a change in atmospheric pressure can lead to changes in surface water $\mathrm{pCO}_{2}$ over short timescales (Burgers et al., 2017) and fluctuations in pH (see Lemasson et al., 2018). Fluctuations can also arise from close proximity to $\mathrm{CO}_{2}$ vents (Hall-Spencer et al., 2008), the introduction of acidified water from coastal upwelling (Feely et al., 2008; Booth et al., 2012), and freshwater inputs (Aguilera et al., 2013; Waldbusser and Salisbury, 2014). Photosynthesis, respiration and the calcification and dissolution of biomineralized structures can also remove and release carbonate $\left(\mathrm{CO}_{3}{ }^{2-}\right)$ ions (Anthony et al., 2011). In marine systems, individuals may therefore be exposed to rapid and acute perturbations of $\mathrm{pH}$ rather than long-term, chronic exposure to reduced $\mathrm{pH}$ as simulated in some mesocosm experiments with conditions varying over spatio-temporal scales. The impact of OA and warming may therefore vary greatly across spatial and temporal scales (e.g., Kurihara et al., 2007; Kurihara, 2008; Thomsen and Melzner, 2010; Fitzer et al., 2015a; Lemasson et al., 2018). Any response may also be context specific and dependent upon individual factors such as the acclimatory capacity and/or evolutionary origins of the target organism (Matoo et al., 2013 and references therein; Ramajo et al., 2019; Britton et al., 2019), capacity to perform biomineralization under variable environmental conditions (Day et al., 2000), or susceptibility to dissolution depending on the mineralogy of their shells (Melzner et al., 2011; Olson et al., 2013). Indeed, current evidence indicates that natural $\mathrm{pH}$ fluctuations can influence the impacts of OA on bio-mineralizing organisms (Wahl et al., 2016) or have no effect, even among species within the same genera (Frieder et al., 2014; Lemasson et al., 2017b, 2018).

Should change to the ultrastructural integrity and strength of individuals occur, there are potentially important ramifications for the fitness and survivorship of bivalve mollusks in the future. Given the common role of bivalves as ecosystem engineers (sensu Jones et al., 1994) in supporting biodiversity, a reduction in shell strength may lead to greater susceptibility to predation and wider multitrophic impacts. For instance, predators of Mytilus sp. (e.g., Carcinus maenas, Nucella lapillus) typically use crushing or boring to penetrate the shell (Elner, 1978; Sadler et al., 2018). Furthermore, predators of bivalve mollusks may themselves become susceptible to OA through impacts on fitness (Whiteley, 2011; Landes and Zimmer, 2012; Sadler et al., 2018), feeding structures (Landes and Zimmer, 2012) and predatory behavior (Dixson et al., 2010; Queiros et al., 2015; Sadler et al., 2018).

In recent years, there has been a burgeoning of studies assessing the effects of future climate change scenarios on the fitness, physiology, and provision of ecosystem services in a plethora of marine species at both the macroscale, and increasingly, microscale. Many earlier studies have shown detrimental impacts of $\mathrm{OA}$ and warming scenarios on species performance, but increasingly, others do not (see Clark et al., 2020). Here, our results indicate that future predictions of sea surface temperature are likely to have detrimental effects on the ultrastructure of Mytilus sp., but when combined with atmospheric $\mathrm{pCO}_{2}$ concentrations predicted for 2100, those negative effects will be in part, ameliorated. These results further muddy the waters in terms of forming generic conclusions about the impact of climate change on marine organisms. It is important to recognize that in many instances, daily fluctuations in $\mathrm{pCO}_{2}$ will be experienced by organisms in surface waters, that will change over spatial and temporal scales depending on environment. This presents challenges when making predictions of a general response of organisms to future climate conditions. We therefore propose that understanding how organisms respond to small and large-scale spatio-temporal fluctuations in future environmental conditions is the next challenge to predicting impacts and further disentangling the consequences of climate change.

\section{DATA AVAILABILITY STATEMENT}

The datasets presented in this article are not readily available because the dataset contains yet to be processed data and is therefore not freely available for use. Requests to access the datasets should be directed to AK, aknights@plymouth.ac.uk.

\section{AUTHOR CONTRIBUTIONS}

$\mathrm{AK}$, NS, and AL devised the research and wrote the draft manuscript. $\mathrm{MN}$ and $\mathrm{AL}$ ran OAW experiments. $\mathrm{MN}$ and $\mathrm{NS}$ performed SEM analysis. All authors contributed to the article and approved the submitted version.

\section{FUNDING}

Funding support was provided by the School of Biological and Marine Sciences and the Faculty of Science and Engineering to AK and NS.

\section{ACKNOWLEDGMENTS}

We thank the editor and two reviewers for their comments that have helped to improve this manuscript. Thanks to Glenn Harper for SEM technical support within Plymouth Electron Microscopy Centre, as well as Rob Hall (School of Geography, Earth and Environmental Sciences) for specimen preparation support.

\section{SUPPLEMENTARY MATERIAL}

The Supplementary Material for this article can be found online at: https://www.frontiersin.org/articles/10.3389/fmars.2020. 567228/full\#supplementary-material

TABLE S1 | Summary of monitoring data from replicate chambers under different temperature and $\mathrm{pCO}_{2}$ treatments in a seawater system. All parameters are displayed as mean $( \pm \mathrm{SD})$. 


\section{REFERENCES}

Aguilera, V. M., Vargas, C. A., Manriquez, P. H., Navarro, J. M., and Duarte, C. (2013). Low-pH freshwater discharges drive spatial and temporal variations in life history traits of neritic copepod Acartia tonsa. Estuaries Coasts 36, 1084-1092. doi: 10.1007/s12237-013-9615-2

Anthony, K. R. N., Kleypas, J. A., and Gattuso, J. P. (2011). Coral reefs modify their seawater carbon chemistry - implications for impacts of ocean acidification. Glob. Change Biol. 17, 3655-3666. doi: 10.1111/j.1365-2486.2011. 02510.x

Arafin, M. A., and Szpunar, J. A. (2009). A new understanding of intergranular stress corrosion cracking resistance of pipeline steel through grain boundary character and crystallographic texture studies. Corros. Sci. 51, 119-128. doi: 10.1016/j.corsci.2008.10.006

Beniash, E., Ivanina, A., Lieb, N. S., Kurochkin, I., and Sokolova, I. M. (2010). Elevated level of carbon affects metabolism and shell formation in oysters Crassostrea virginica. Mar. Ecol. Prog. Ser. 419, 95-108. doi: 10.3354/meps 08841

Bibby, R., Cleall-Harding, P., Rundle, S., Widdicombe, S., and Spicer, J. (2007). Ocean acidification disrupts induced defences in the intertidal gastropod Littorina littorea. Biol. Lett. 3, 699-701. doi: 10.1098/rsbl.2007. 0457

Booth, J. A. T., McPhee-Shaw, E. E., Chua, P., Kingsley, E., Denny, M., Phillips, R., et al. (2012). Natural intrusions of hypoxic, low pH water into nearshore marine environments on the California coast. Cont. Shelf Res. 45, 108-115. doi: 10.1016/j.csr.2012.06.009

Britton, D., Mundy, C. N., McGraw, C. M., Revill, A. T., and Hurd, C. L. (2019). Responses of seaweeds that use $\mathrm{CO} 2$ as their sole inorganic carbon source to ocean acidification: differential effects of fluctuating $\mathrm{pH}$ but little benefit of CO2 enrichment. ICES J. Mar. Sci. 76, 1860-1870. doi: 10.1093/icesjms/ fsz070

Burgers, T. M., Miller, L. A., Thomas, H., Else, B. G. T., Gosselin, M., and Papakyriakou, T. (2017). Surface water pCO2 variations and sea-air CO2 fluxes during summer in the Eastern Canadian Arctic. J. Geophys. Res. Oceans 122, 9663-9678. doi: 10.1002/2017jc013250

Checa, A. G., Okamoto, T., and Ramirez, J. (2006). Organization pattern of nacre in Pteriidae (Bivalvia: Mollusca) explained by crystal competition. Proc. R. Soc. B Biol. Sci. 273, 1329-1337. doi: 10.1098/rspb.2005.3460

Choi, C. S., and Kim, Y. W. (2000). A study of the correlation between organic matrices and nanocomposite materials in oyster shell formation. Biomaterials 21, 213-222. doi: 10.1016/s0142-9612(99)00120-9

Clark, T. D., Raby, G. D., Roche, D. G., Binning, S. A., Speers-Roesch, B., Jutfelt, F., et al. (2020). Ocean acidification does not impair the behaviour of coral reef fishes. Nature 577, 370-375. doi: 10.1038/s41586-019-1903-y

Coleman, D. W., Byrne, M., and Davis, A. R. (2014). Molluscs on acid: gastropod shell repair and strength in acidifying oceans. Mar. Ecol. Prog. Ser. 509, 203-211. doi: $10.3354 /$ meps10887

Comeau, S., Edmunds, P. J., Spindel, N. B., and Carpenter, R. C. (2014). Diel pCO2 oscillations modulate the response of the coral Acropora hyacinthus to ocean acidification. Mar. Ecol. Prog. Ser. 501, 99-111. doi: 10.3354/meps 10690

Day, E. G., Branch, G. M., and Viljoen, C. (2000). How costly is molluscan shell erosion? A comparison of two patellid limpets with contrasting shell structures. J. Exp. Mar. Biol. Ecol. 243, 185-208. doi: 10.1016/s0022-0981(99)00120-3

Dixson, D. L., Munday, P. L., and Jones, G. P. (2010). Ocean acidification disrupts the innate ability of fish to detect predator olfactory cues. Ecol. Lett. 13, 68-75. doi: 10.1111/j.1461-0248.2009.01400.x

Doney, S. C., Fabry, V. J., Feely, R. A., and Kleypas, J. A. (2009). Ocean acidification: the other CO2 problem. Annu. Rev. Mar. Sci. 1, 169-192.

Dufault, A. M., Cumbo, V. R., Fan, T. Y., and Edmunds, P. J. (2012). Effects of diurnally oscillating $\mathrm{pCO}(2)$ on the calcification and survival of coral recruits. Proc. R. Soc. B Biol. Sci. 279, 2951-2958. doi: 10.1098/rspb.2011. 2545

Dupont, S., Dorey, N., Stumpp, M., Melzner, F., and Thorndyke, M. (2013). Longterm and trans-life-cycle effects of exposure to ocean acidification in the green sea urchin Strongylocentrotus droebachiensis. Mar. Biol. 160, 1835-1843. doi: 10.1007/s00227-012-1921-x

Elner, R. W. (1978). Mechanics of predation by shore crab, Carcinus maenas (L), on edible mussel, Mytilus edulis L. Oecologia 36, 333-344. doi: 10.1007/bf00348059
Feely, R. A., Sabine, C. L., Hernandez-Ayon, J. M., Ianson, D., and Hales, B. (2008). Evidence for upwelling of corrosive" acidified" water onto the continental shelf. Science 320, 1490-1492. doi: 10.1126/science.1155676

Fitzer, S. C., Chung, P., Maccherozzi, F., Dhesi, S. S., Kamenos, N. A., Phoenix, V. R., et al. (2016). Biomineral shell formation under ocean acidification: a shift from order to chaos. Sci. Rep. 6:21076.

Fitzer, S. C., Cusack, M., Phoenix, V. R., and Kamenos, N. A. (2014a). Ocean acidification reduces the crystallographic control in juvenile mussel shells. J. Struct. Biol. 188, 39-45. doi: 10.1016/j.jsb.2014.08.007

Fitzer, S. C., Phoenix, V. R., Cusack, M., and Kamenos, N. A. (2014b). Ocean acidification impacts mussel control on biomineralisation. Sci. Rep. 4: 6218.

Fitzer, S. C., Vittert, L., Bowman, A., Kamenos, N. A., Phoenix, V. R., and Cusack, M. (2015a). Ocean acidification and temperature increase impact mussel shell shape and thickness: problematic for protection? Ecol. Evol. 5, 4875-4884. doi: 10.1002/ece3.1756

Fitzer, S. C., Zhu, W. Z., Tanner, K. E., Phoenix, V. R., Kamenos, N. A., and Cusack, M. (2015b). Ocean acidification alters the material properties of Mytilus edulis shells. J. R. Soc. Interface 12:20141227. doi: 10.1098/rsif.2014.1227

Fortes, M. A. (1972). Coincidence site lattices. Phys. Status Solidi B Basic Res. 54, 311-319. doi: 10.1002/pssb.2220540131

Frieder, C. A., Gonzalez, J. P., Bockmon, E. E., Navarro, M. O., and Levin, L. A. (2014). Can variable $\mathrm{pH}$ and low oxygen moderate ocean acidification outcomes for mussel larvae? Glob. Change Biol. 20, 754-764. doi: 10.1111/gcb. 12485

Fryda, J., Klicnarova, M., Frydova, B., and Mergl, M. (2010). Variability in the crystallographic texture of bivalve nacre. Bull. Geosci. 85, 645-662. doi: 10. 3140/bull.geosci.1217

Füllenbach, C. S., Schonë, B. R., and Branscheid, R. (2014). Microstructures in shells of the freshwater gastropod Viviparus viviparus: a potential sensor for temperature change? Acta Biomater. 10, 3911-3921. doi: 10.1016/j.actbio.2014. 03.030

Gazeau, F., Parker, L. M., Comeau, S., Gattuso, J. P., O'Connor, W. A., Martin, S., et al. (2013). Impacts of ocean acidification on marine shelled molluscs. Mar. Biol. 160, 2207-2245. doi: 10.1007/s00227-013-2219-3

Gilbert, P. U. P. A., Bergmann, K. D., Myers, C. E., Marcus, M. A., Devol, R. T., Sun, C. Y., et al. (2017). Nacre tablet thickness records formation temperature in modern and fossil shells. Earth Planet. Sci. Lett. 460, 281-292. doi: 10.1016/ j.epsl.2016.11.012

Glazier, A., Herrera, S., Weinnig, A., Kurman, M., Gómez, C. E., and Cordes, E. (2020). Regulation of ion transport and energy metabolism enables certain coral genotypes to maintain calcification under experimental ocean acidification. Mol. Ecol. 29, 1657-1673. doi: 10.1111/mec.15439

Goetz, A. J., Steinmetz, D. R., Griesshaber, E., Zaefferer, S., Raabe, D., Kelm, K., et al. (2011). Interdigitating biocalcite dendrites form a 3-D jigsaw structure in brachiopod shells. Acta Biomater. 7, 2237-2243. doi: 10.1016/j.actbio.2011.01. 035

Hahn, S., Rodolfo-Metalpa, R., Griesshaber, E., Schmahl, W. W., Buhl, D., Hall-Spencer, J. M., et al. (2012). Marine bivalve shell geochemistry and ultrastructure from modern low $\mathrm{pH}$ environments: environmental effect versus experimental bias. Biogeosciences 9, 1897-1914. doi: 10.5194/bg-9-18972012

Hall-Spencer, J. M., Rodolfo-Metalpa, R., Martin, S., Ransome, E., Fine, M., Turner, S. M., et al. (2008). Volcanic carbon dioxide vents show ecosystem effects of ocean acidification. Nature 454, 96-99. doi: 10.1038/nature0 7051

Hiebenthal, C., Philipp, E. E. R., Eisenhauer, A., and Wahl, M. (2013). Effects of seawater $\mathrm{pCO} 2$ and temperature on shell growth, shell stability, condition and cellular stress of Western Baltic Sea Mytilus edulis (L.) and Arctica islandica (L.). Mar. Biol. 160, 2073-2087. doi: 10.1007/s00227-012-2080-9

Hofmann, G. E., Smith, J. E., Johnson, K. S., Send, U., Levin, L. A., Micheli, F., et al. (2011). High-frequency dynamics of ocean $\mathrm{pH}$ : a multi-ecosystem comparison. PLoS One 6:e28983. doi: 10.1371/journal.pone.0028983

Huning, A., Melzner, F., Thomsen, J., Gutowska, M. A., Kramer, L., Frickenhaus, S., et al. (2013). Impacts of seawater acidification on mantle gene expression patterns of the Baltic Sea blue mussel: implications for shell formation and energy metabolism. Mar. Biol. 160, 1845-1861. doi: 10.1007/s00227-0121930-9 
IPCC (2014). Climate Change 2014: Synthesis Report. Contribution of Working Groups I, II and III to the Fifth Assessment Report of the Intergovernmental Panel on Climate Change. Geneva: IPCC.

Jones, C. G., Lawton, J. H., and Shachak, M. (1994). Organisms as ecosystem engineers. Oikos 69, 373-386. doi: 10.2307/3545850

Kurihara, H. (2008). Effects of CO2-driven ocean acidification on the early developmental stages of invertebrates. Mar. Ecol. Prog. Ser. 373, 275-284. doi: 10.3354/meps07802

Kurihara, H., Kato, S., and Ishimatsu, A. (2007). Effects of increased seawater pCO2 on early development of the oyster Crassostrea gigas. Aquat. Biol. 1, 91-98. doi: 10.3354/ab00009

Lagos, N. A., Benitez, S., Duarte, C., Lardies, M. A., Broitman, B. R., Tapia, C., et al. (2016). Effects of temperature and ocean acidification on shell characteristics of Argopecten purpuratus: implications for scallop aquaculture in an upwellinginfluenced area. Aquacult. Environ. Interact. 8, 357-370. doi: 10.3354/aei00183

Landes, A., and Zimmer, M. (2012). Acidification and warming affect both a calcifying predator and prey, but not their interaction. Mar. Ecol. Prog. Ser. 450, 1-10. doi: 10.3354/meps09666

Lehockey, E. M., Brennenstuhl, A. M., and Thompson, I. (2004). On the relationship between grain boundary connectivity, coincident site lattice boundaries, and intergranular stress corrosion cracking. Corros. Sci. 46, 23832404. doi: 10.1016/j.corsci.2004.01.019

Lemasson, A. J., Fletcher, S., Hall-Spencer, J. M., and Knights, A. M. (2017a). Linking the biological impacts of ocean acidification on oysters to changes in ecosystem services: a review. J. Exp. Mar. Biol. Ecol. 492, 49-62. doi: 10.1016/j. jembe.2017.01.019

Lemasson, A. J., Kuri, V., Hall-Spencer, J. M., Fletcher, S., Moate, R., and Knights, A. M. (2017b). Sensory qualities of oysters unaltered by a short exposure to combined elevated pCO2 and temperature. Front. Mar. Sci. 4:352. doi: 10.3389/ fmars.2017.00352

Lemasson, A. J., Hall-Spencer, J. M., Fletcher, S., Provstgaard-Morys, S., and Knights, A. M. (2018). Indications of future performance of native and nonnative adult oysters under acidification and warming. Mar. Environ. Res. 142, 178-189. doi: 10.1016/j.marenvres.2018.10.003

Leung, J. Y., Russell, B. D., and Connell, S. D. (2020). Linking energy budget to physiological adaptation: how a calcifying gastropod adjusts or succumbs to ocean acidification and warming. Sci. Total Environ. 715:136939. doi: 10.1016/ j.scitotenv.2020.136939

Li, S., Huang, J., Liu, C., Liu, Y., Zheng, G., Xie, L., et al. (2016). Interactive effects of seawater acidification and elevated temperature on the transcriptome and biomineralization in the pearl oyster Pinctada fucata. Environ. Sci. Technol. 50, 1157-1165. doi: 10.1021/acs.est.5b05107

Li, S. G., Liu, C., Huang, J. L., Liu, Y. J., Zheng, G. L., Xie, L. P., et al. (2015). Interactive effects of seawater acidification and elevated temperature on biomineralization and amino acid metabolism in the mussel Mytilus edulis. J. Exp. Biol. 218, 3623-3631. doi: 10.1242/jeb.126748

Lindinger, M. I., Lauren, D. J., and Mcdonald, D. G. (1984). Acid-base balance in the sea mussel, Mytilus edulis. III: effects of environmental hypercapnia on intra- and extracellular acid-base balance. Mar. Biol. Lett. 5, 371-381.

Mackenzie, C. L., Ormondroyd, G. A., Curling, S. F., Ball, R. J., Whiteley, N. M., and Malham, S. K. (2014). Ocean warming, more than acidification, reduces shell strength in a commercial shellfish species during food limitation. PLoS One 9:e86764. doi: 10.1371/journal.pone.0086764

Maier, B. J., Griesshaber, E., Alexa, P., Ziegler, A., Ubhi, H. S., and Schmahl, W. W. (2014). Biological control of crystallographic architecture: hierarchy and coalignment parameters. Acta Biomater. 10, 3866-3874. doi: 10.1016/j.actbio. 2014.02.039

Marin, F., and Luquet, G. (2004). Molluscan shell proteins. C. R. Palevol 3, 469-492. doi: 10.1016/j.crpv.2004.07.009

Matoo, O. B., Ivanina, A. V., Ullstad, C., Beniash, E., and Sokolova, I. M. (2013). Interactive effects of elevated temperature and CO2 levels on metabolism and oxidative stress in two common marine bivalves (Crassostrea virginica and Mercenaria mercenaria). Comp. Biochem. Physiol. A Mol. Integr. Physiol. 164, 545-553. doi: 10.1016/j.cbpa.2012.12.025

Melatunan, S., Calosi, P., Rundle, S. D., Widdicombe, S., and Moody, A. J. (2013). Effects of ocean acidification and elevated temperature on shell plasticity and its energetic basis in an intertidal gastropod. Mar. Ecol. Prog. Ser. 472, 155-168. doi: $10.3354 /$ meps 10046
Melzner, F., Stange, P., Trubenbach, K., Thomsen, J., Casties, I., Panknin, U., et al. (2011). Food supply and seawater pCO2 impact calcification and internal shell dissolution in the blue mussel Mytilus edulis. PLoS One 6:e24223. doi: 10.1371/journal.pone.0024223

Meng, Y., Guo, Z., Yao, H., Yeung, K. W., and Thiyagarajan, V. (2019). Calcium carbonate unit realignment under acidification: a potential compensatory mechanism in an edible estuarine oyster. Mar. Pollut. Bull. 139, 141-149.

Nakahara, H. (1991). "Nacre formation in bivalve and gastropod molluscs," in Mechanisms and Phylogeny of Mineralization in Biological Systems, eds S. Suga and H. Nakahara (Tokyo: Springer), 343-350.

Olson, I. C., Blonsky, A. Z., Tamura, N., Kunz, M., Pokroy, B., Romao, C. P., et al. (2013). Crystal nucleation and near-epitaxial growth in nacre. J. Struct. Biol. $184,454-463$.

Olson, I. C., and Gilbert, P. U. P. A. (2012). Aragonite crystal orientation in mollusk shell nacre may depend on temperature. The angle spread of crystalline aragonite tablets records the water temperature at which nacre was deposited by Pinctada margaritifera. Faraday Discuss. 159, 421-432.

Oxford Instruments (2015). EBSD Explained: from Data Acquisition to Advanced Analysis. Abingdon: Oxford Instruments.

Pansch, C., Schaub, I., Havenhand, J., and Wahl, M. (2014). Habitat traits and food availability determine the response of marine invertebrates to ocean acidification. Glob. Change Biol. 20, 765-777.

Pinheiro, J., Bates, D., DebRoy, S., Sarkar, D., and R Core Team (2020). nlme: Linear and Nonlinear Mixed Effects Models. R package version 3.1-144.

Queiros, A. M., Fernandes, J. A., Faulwetter, S., Nunes, J., Rastrick, S. P. S., Mieszkowska, N., et al. (2015). Scaling up experimental ocean acidification and warming research: from individuals to the ecosystem. Glob. Change Biol. 21, $130-143$.

R Development Core Team (2017). R: A Language and Environment for Statistical Computing. Vienna: R Foundation for Statistical Computing.

Ramajo, L., Lagos, N. A., and Duarte, C. M. (2019). Seagrass Posidonia oceanica diel $\mathrm{pH}$ fluctuations reduce the mortality of epiphytic forams under experimental ocean acidification. Mar. Pollut. Bull. 146, 247-254.

Sadler, D. E., Lemasson, A. J., and Knights, A. M. (2018). The effects of elevated $\mathrm{CO} 2$ on shell properties and susceptibility to predation in mussels Mytilus edulis. Mar. Environ. Res. 139, 162-168.

Scanes, E., Parker, L. M., O’Connor, W. A., Stapp, L. S., and Ross, P. M. (2017). Intertidal oysters reach their physiological limit in a future high-CO2 world. J. Exp. Biol. 220, 765-774.

Sokal, R. R., and Rohlf, F. J. (1995). Biometry, 3rd Edn. New York, NY: W.H. Freeman and Company.

Stocker, T., Qin, D., Plattner, G., Tignor, M., Allen, S., Boschung, J., et al. (2013). IPCC, 2013: Climate Change 2013: the Physical Science Basis. Contribution of Working Group I to the Fifth Assessment Report of the Intergovernmental Panel on Climate Change. Cambridge: Cambridge University Press.

Thomsen, J., and Melzner, F. (2010). Moderate seawater acidification does not elicit long-term metabolic depression in the blue mussel Mytilus edulis. Mar. Biol. $157,2667-2676$.

Wahl, M., Saderne, V., and Sawall, Y. (2016). How good are we at assessing the impact of ocean acidification in coastal systems? Limitations, omissions and strengths of commonly used experimental approaches with special emphasis on the neglected role of fluctuations. Mar. Freshw. Res. 67, 25-36.

Waldbusser, G. G., and Salisbury, J. E. (2014). Ocean acidification in the coastal zone from an organism's perspective: multiple system parameters, frequency domains, and habitats. Annu. Rev. Mar. Sci. 6, 221-247.

Whiteley, N. M. (2011). Physiological and ecological responses of crustaceans to ocean acidification. Mar. Ecol. Prog. Ser. 430, 257-271.

Conflict of Interest: The authors declare that the research was conducted in the absence of any commercial or financial relationships that could be construed as a potential conflict of interest.

Copyright (c) 2020 Knights, Norton, Lemasson and Stephen. This is an open-access article distributed under the terms of the Creative Commons Attribution License (CC BY). The use, distribution or reproduction in other forums is permitted, provided the original author(s) and the copyright owner(s) are credited and that the original publication in this journal is cited, in accordance with accepted academic practice. No use, distribution or reproduction is permitted which does not comply with these terms. 